\title{
PENINGKATAN KEMAMPUAN MANTAN TENAGA KERJA INDONESIA MELALUI PELATIHAN SABLON AGAR DAPAT BERWIRAUSAHA
}

\author{
Etin Solihatin ${ }^{1}$, adi wijanarko ${ }^{2}$ \\ Jurusan PPKN Fakultas Ilmu Sosial Universitas Negeri Jakarta \\ etinsolihatin@yahoo.com
}

\begin{abstract}
ABSTRAK
Pengabdian Pada Masyarakat (P2M) adalah salah satu dari Tridharma Perguruan Tinggi yang wajib dilaksanakan oleh setiap dosen. Pelaksanaan pengabdian yang berupa pelatihan pada para mantan Tenaga Kerja Indonesia di Desa Mekarsari Kecamatan Jatisari Kabupaten Karawang Jawa Barat.

Pelatihan pembuatan produk sablon pada baju kaos, menghasilkan motivasi dan kreativitas pada kaum para mantan Tenaga Kerja Indonesia (TKI), sehingga dalam waktu luangnya mereka dapat mengisi kegiatan kosong dengan membuat produk yang bermanfaat dan memberikan keterampilan baru.

Hasil yang diperoleh berupa produk baju kaos bersablon yang bertuliskan desa Mekarsari dipergunakan mereka masing-masing. Diharapkan mereka dapat berwirausaha dari hasil keterampilan pelatihan sablon, sehingga pada akhirnya dapat meningkatkan penghasilan untuk keluarga.
\end{abstract}

Kata Kunci : kaos, Produk, sablon

\section{PENDAHULUAN}

Globalisasi telah menimbulkan dampak yang besar bagi perekonomian, meskipun menimbulkan dampak negatif bagi masyarakat. Kemiskinan dan tidak meratanya distribusi pendapatan yang diakibatkan oleh tidak meratanya distribusi kesempatan dan lapangan pekerjaan antara wilayah pedesaan dan perkotaan.

Sulitnya memperoleh pekerjaan di dalam negeri mendorong sebagian pekerja mengadu nasib di luar negeri. Rendahnya pendidikan calon TKI mengakibatkan mereka menghadapi resiko mudah ditipu pihak lain.

Para calon TKI tidak memahami aturan dan persyaratan untuk bekerja di luar negeri. Dengan pendidikan yang kurang mendukung dan pelatihan yang diberikan oleh BNP2 TKI, serta lulus seleksi, maka berangkatlah mereka ke negara tujuan. Dengan harapan mendapat upah yang besar, dengan resiko seminim mungkin. Para TKI bekerja di luar negeri lamanya sesuai kontrak, yang pada akhirnya pulang kembali ke tanah air.

Setibanya di tanah air diharapkan para TKI tidak kembali lagi ke negara lain. Dengan sisa upah yang ada harusnya mereka belajar mandiri. Sesuai harapan direktur karier dan SDM, Kemenristek DIKTI, para TKI ini harus bisa berwirausaha dan menambah keterampilannya. Untuk merealisasikan harapan Direktur Karier dan SDM tim pengabdian masyarakat ingin menyumbangkan sedikit keterampilan, dan berdasarkan observasi awal keterampilan yang diinginkan adalah "sablon". Untuk itulah pelatihan ini akan dilaksanakan.

Dengan berlatih sablon secara baik, maka para TKI bisa menjual hasil produknya ke tempat wisata atau dipasarkan di tempat lain. Lambat laun kebutuhan hidupnya dapat dipenuhi dari hasil usaha mereka di Indonesia, dengan dukungan dana yang dibawa dari luar negeri.

\section{A. PERUMUSAN MASALAH}

Berdasarkan analisis situasi di atas, maka masalah dalam kegiatan ini dirumuskan sebagai berikut: "Bagaimana memberikan pelatihan keterampilan sablon kepada para TKI agar mereka bisa berwirausaha dan tidak kembali lagi ke luar negeri?"

\section{B. TUJUAN KEGIATAN}

Kegiatan pengabdian masyarakat ini memiliki tujuan sebagai berikut :

1. Meningkatkan pengetahuan dan keterampilan bagi para TKI mengenai 
sablon dan memasarkan produk/hasil kegiatannya dengan baik.

2. Memberi solusi dalam memanfaatkan sisa upah dari luar negeri untuk dijadikan modal awal usahanya, dengan keterampilan sablon.

3. Melatih mengemas/pack produk, untuk dipasarkan lebih menarik dan laku di pasaran.

\section{MANFAAT KEGIATAN}

Adapun manfaat kegiatan pengabdian masyarakat ini yaitu:

1. Adanya peningkatan keterampilan sablon bagi para TKI untuk meningkatkan pendapatan, sehingga dalam memenuhi kebutuhan rumah tangganya tidak perlu ke luar negeri lagi, tapi cukup berwirausaha di dalam negeri.

2. Adanya peningkatan kemampuan "mengemas" dan "memasarkan" hasil produk sablon yang dibuatnya.

\section{KAJIAN PUSTAKA}

\section{A. TENAGA KERJA INDONESIA}

Tenaga Kerja Indonesia (TKI) adalah sebutan bagi warga negara Indonesia yang lowlife dan unskill yang bekerja di luar negeri (seperti: Malaysia, Timur Tengah, Taiwan, dan Iain-Iain) dalam hubungan kerja untuk jangka waktu tertentu dengan menerima upah (https:// id.wikipedia.org./wiki/Tenaga-Kerja-lndonesia). Namun istilah TKI sering dikonotasikan dengan pekerja kasar atau kumpulan tenaga kerja unskill yang merupakan program pemerintah untuk menekan angka pengangguran.

TKI sering disebut sebagai pahlawan devisa karena dalam setahun bisa menghasilkan devisa 60 triliun rupiah (2006), tetapi dalam kenyataannya menjadi ajang pungli bagi para pejabat dan agen terkait. Bahkan di Bandara Soekamo-Hatta, mereka disediakan terminal tersendiri (Terminal III) yang terpisah dari terminal penumpang umum. Pemisahan ini beralasan untuk melindungi TKI, namun menyuburkan pungli.

Untuk menghadapi image TKI adalah tenaga kerja yang unskill yang bekerja di luar negeri, agar kemampuan and keterampilan calon TKI sesuai dengan persyaratan yang diminta pengguna di luar negeri. Sebelum diberangkatkan para calon TKI harus mengikuti kegiatan pelatihan, dengan materi :

1) Keterampilan khusus, sesuai dengan permintaan di luar negeri

2) Bahasa negara tujuan

3) Hukum dan adat istiadat negara tujuan

4) Jangka waktu pelatihan 23-90 hari tergantung jenis pekerjaan dan negara tujuan

5) Informasi tenaga kebijakan pemerintah Rl tentang pengiriman TKI ke luar negeri (bptkit.disnakertrans.jabarprov. go.id/index.php/slide/ index/ 15).

Namun yang menjadi tantangan selanjutnya diantaranya bagaimana upah yang mereka bawa (sebagian) dapat dijadikan untuk modal selanjutnya, sehingga mereka (TKI) dapat berwirausaha dan tidak kembali lagi ke luar negeri. Hal ini menjadi salah satu pemikiran dari tim pengabdian masyarakat untuk memberi pelatihan sablon, sesuai hasil survey awal tentang minat TKI tentang sablon, agar hasilnya dapat dijual di daerah wisata.

\section{B. MATERI KETERAMPILAN SABLON}

Sablon adalah istilah umum yang khalayak masyarakat lebih mengenalnya. Istilah sablon dalam dunia keilmuan yaitu Pencapan. Pencapan adalah proses pemberian motif di atas benda atau kain dengan cara mencetak melalui screen yang telah didesain motifnya, adapun proses pemberian warna dengan menggunakan zat pengental, zat warna dan zat pengikat, melalui penekanan dengan alat rakel.

Teknik Pencapan dengan menggunakan kassa screen adalah proses pemberian motif diatas benda atau kain adalah proses pemberian motif teknik cara lama. Namun diyakini bahwa teknik pencapan ini sangat mudah, dan banyak hasilnya serta kualaitas yang baik. Teknik pencapan biasanya dilakukan diatas kain baju, kaos guna memberilkan corak desain motif yang lebih menonjol.

Teknik pencapan ini menggunakan kassa screen yang terbuat dari kain sutera polyester 
dengan pori-pori yang sangat halus agar transfer saring warna pada kain merata dan sempurna. Penekanan dengam menggunakan rakel yang bagian bawahnya adalah plat karet padat agar zat warna dan zat pengental dapat dengan sempurna dan mereata mewarnai permukaan kain yang di cap/disablon.

\section{Teknik Sablon}

a. Teknik mentransfer Motif ke kassa screen

1) Membuat Motif diatas kertas transparant.

2) Mentransfer motif tersebut diatas ke kassa screen. Dengan cara kassa screen diberi dahulu zat Hilex yang berwarna ungu atau biru sebagai zat film. Setelah zat tersebut merata dan kering (saat mengoleskan Hilex pada screen yang telah dibersihkan sebelumnya jangan kena cahaya matahari dan lampu langsung karena lapisan film akan gagal saat proses transfer motif)

3) Melakukan transfer motif dengan pencahayaan matahari pada jam 11 - 15.00 selama 1 menit atau lampu neon TL 40watt selama 15 menit.

Jika menggunakan lampu neon TL. Posisi lampu dibawah dan bantalan hitam di bagian paling atas. Dengan posisi kaca tetap menghadap langsung pada sumber cahaya sebagai media mentraser motif dari motif dikertas ke kassa screen.

4) Setelah proses pentrasferan motif selesai. Kassa screen dicuci dengan air mengalir agar sisi-sisi motif Nampak jelas tergambar. Kemudian keringkan.

\section{b. Persiapan Cetak Sablon}

Setelah kassa screen selesai dilakukan pemindahan motif. Langkah selanjutnya proses penyablonan pada kain/kaos/ benda lain. Dengan cara membuat terlebih dahulu pasta cap yang berupa: zat warna, zat pengental, zat pengikat (binder) yang diaduk merata. Kekentelan pasta cap harus sesuai tidak terlalu kental dan tidak terlalu encer.

\section{Transfer Printing.}

Metode lain teknik sablon adalah dengan teknik transfer printing. Metoda ini lebih praktis, yaitu hanya dengan menggunakan kertas transfer printing yang di printkan motif gambarnya dengan tinta printer berwarna, kemudian proses pemindahan motifnya dengan teknik pemanasan, atau penyetrikaan di atas permukaan kain/kaos.

\section{METODE PELAKSANAAN}

\section{A. METODE PEMECAHAN MASALAH}

Agar pelatihan sablon bagi para TKI dapat berjalan dengan baik, harus melalui tahapan:

1. Memberikan "informasi penting" berkaitan dengan sablon

2. Praktek pembuatan sablon dengan gambar, dan kata-kata yang menarik namun tetap rasionalisme oleh instruktur disaksikan oleh peserta

3. Praktek sablon oleh seluruh peserta, dengan bahan kaos (kaos untuk anak-anak dan dewasa), namun tetap didampingi instruktur

4. Teknik "mengemas" hasil produksi agar bagus, menarik dan mutu terjamin

5. Memberikan "informasi tentang teknik pemasaran" (menjual produk)

\section{B. KERANGKA PEMECAHAN MASALAH}

Salah satu upaya yang dapat dilaksanakan dalam rangka pemecahan masalah "agar TKI dapat memiliki keterampilan sablon dan sanggup berwirausaha" yaitu pelatihan sablon, dilakukan dengan tahapan sebagai berikut :

1. Mengadakan koordinasi dengan pihak kelurahan, LPM, nara sumber, dan para TKI yang sudah pulang dari luar negeri dan berminat berwirausaha.

2. Menggandakan materi power point, menyiapkan kaos anak-anak dan dewasa, foto/gambar/tulisan yang akan dimuat di "gambar" pada kaos.

3. Melaksanakan program pelatihan sablon, praktek mengemas, dan praktek 
pemasaran

4. Melakukan evaluasi program dan penyusunan laporan.

\section{KHALAYAK SASARAN}

Khalayak sasaran yang dianggap strategis dapat tepat yaitu para TKI yang sudah pulang dari luar negeri, dan berniat akan berwirausaha, agar tidak kembali lagi ke luar negeri, untuk dilibatkan dalam pelatihan sablon.

\section{TEMPAT DAN WAKTU KEGIATAN}

Kegiatan pelatihan ini dilaksanakan di rumah warga yang memiliki tempat yang mendukung program pelatihan sablon ini. Waktu kegiatan pada tanggal 14 Agustus 2016.

\section{HASIL DAN PEMBAHASAN}

\section{A. HASIL KEGIATAN}

Setelah megikuti pelatihan ini peserta pelatihan sablon yang umumnya para TKI yang sudah pulang dari luar negeri menguasai teknik penyablonan, bahan baku yang digunakan juga sangat terjangkau dan mudah didapat, pembuatannya pun relatif mudah. Tergantung kemauan dari para pesertanya itu sendiri untuk selalu mencoba dan berinovasi.

Dalam pelatihan ini, para peserta yaitu para TKI ini langsung terjun dalam praktek sablon sehingga mereka yang umumnya para wanita ini mempunyai kesempatan langsung untuk menyablon sendiri dan hasilnya pada kaos langsung dapat mereka pakai. Proses penyablonan ini relatif tidak sulit, dapat pula dijadikan peluang bisnis yang cukup menjanjikan untuk menambah penghasilan masyarakat itu sendiri. Dalam menyablon ini tidak terlalu lama apalagi kalau mereka sudah terbiasa berlatih tentu akan sangat cepat dalam proses menyablonnya, alat-alat yang digunakan juga relatif lebih mudah dan aman untuk digunakan.

\section{B. PEMBAHASAN}

Lokasi pelatihan diadakan di rumah warga yang memiliki tempat yang mendukung program pelatihan sablon ini yaitu di Wilayah Desa Mekarsari Kecamatan Jatisari Kab. Karawang. Dengan jumlah peserta 47 orang yang berasal dari para TKI yang sudah pulang dari luar negeri dan berniat untuk berwirausaha.

Kegiatan awal dalam pelatihan ini adalah pengenalan mengenai alat-alat sablon. Kemudian dijelaskan bagaimana Teknik penyablonan sederhana yang benar. Selain tahap demi tahap di jelaskan dan dipraktekan. Instruktur pelatihan juga memberikan tips dan beberapa hal yang harus diperhatikan dalam menyablon yang baik.

Berikut adalah bahan dan alat untuk menyablon kaos yang diantaranya adalah :

1) Kaos yang akan dicetak

2) Papan tripleks sesuai besar kaos

3) Rangka/screen dengan gambar yang sudah diafdruk

4) Rakel yang sudah terpasang di pegangan rakel

5) Tinta sablon tekstil

6) Beberapa lembar plastik dan lakban

7) Kain katun perca \& air secukupnya untuk lap sisa tinta.

\section{- Proses Cetak Sablon}

1) Siapkan kaos. Masukkan tatakan tripleks ke dalam kaos agar tinta tidak merembes ke bagian belakang kaos dan menstabilkan kaos waktu disablon.

2) Letakkan rangka/screen/kasa sablon di atas kaos. Posisikan gambar sesuai dengan keinginan perancang.

3) Posisikan rangka screen sesuai rancangan.

4) Tuang tinta di tepi gambar bagian atas dari kita menghadap obyek. Selanjutnya, tarik cat sablon tersebut ke arah ke bawah menggunakan rakel dengan tekanan yang rata, cukup satu kali tarikan.

5) Sablon kaos telah selesai dan lihat hasilnya dengan mengangkat rangka screen perlahan-lahan. Berikutnya keringkan kaos tersebut.

\section{- Proses Pasca Cetak Sablon}

Setiap tinta cetak memerlukan waktu untuk mengering dengan sempurna, bahkan bila kita memegang tinta tersebut dan permukaannya kita rasa telah mengering, belum tentu tinta tersebut telah kering dengan sempurna. Oleh karena itu penting untuk mengenal karakteristik tinta cetak 
yang kita gunakan. Untuk proses ini kita dapat melakukannya dengan melalui proses alami (penjemuran) atau dengan bantuan mesin (kipas angin, blower, dsb).

Bila kaos sudah tersablon, tunggu sampai tinta betul-betul kering sebelum kaos dilipat untuk digunakan. dan Jangan lupa segera bersihkan screen sebersih mungkin dari tinta sablon.

\section{KESIMPULAN}

Kegiatan pelatihan sablon kepada para TKI yang sudah pulang dari luar negeri dan berniat akan berwirausaha, agar tidak kembali lagi ke luar negeri sesuai dengan tujuan program kegiatan, dimana para TKI menjadi memiliki keterampilan, pengetahuan mengenai proses pembuatan sablon. Yang mana dari hasil pelatihan menyablon ini para TKI dapat berwirausaha secara mandiri. Produk hasil sablonnya dapat di pasarkan ke masyarakat luas.

\section{REFERENSI}

Kotler \& Keller. 2012. Manajemen Pemasaran. Edisi 14, New Jersey: Prentice Hall

Kuratko, Donal F; Hodgetts, Richard M. 2013. Entrepreneurship: A Contemporary, Approach Orlando: The Dryden Press.

Kotler, Philip \& Keller; Kevin Lane. 2014. Marketing Manajemen, Jakarta: Erlangga.

Prasetijo, Ristiyanti \& John, J.O.I. 2004, Perilaku Konsumen, Yogyakarta: Andi

Swasta, Bhasu. 2011. Manajemen Pemasaran dan Loyalitas Pelangan. Jakarta: Erlangga

Sumber Internet

https://id.wikipedia.org/wiki/Tenaga_Kerja lndonesia- 